\title{
Unfolding Knowledge on Sexual Violence Experienced by Black Lesbian Survivors in the Townships of Cape Town, South Africa
}

\author{
Jacqueline K. Wilson \\ $\mathrm{PhD}$ student, Rhodes University South Africa, Department of Sociology
}

\begin{abstract}
Sexual violence is conceptualised as a hate or bias-motivated crime, and is recognised as a social problem of global proportion. However, the platform for this paper focuses on incidents of rape in South Africa, a country where the most progressive legislation concerning sexual minorities is enforced, including gender nonconforming people namely Lesbian, Gay, Bisexual, Trans and Intersex (LGBTI). South Africa still must address rape inflicted on black lesbians residing in Cape Town townships, despite gender equality being granted in on the basis of sexual orientation (Silvio, 2011). The same applies to same sex marriages, making South Africa the role model of other African countries yet to be included in the signatory to the 2008 United Nations Human Rights Council Resolution on Sexual Orientation and Gender Identity. An alternative concept to categorising rape as a hate crime might be a more effective tool in the legislation to combat rape based on sexual orientation; justice will be served as a female homosexual enjoys equal citizenship as that of a heterosexual citizen. Preliminary findings show that some rape victims became mothers as a result of the rape. Rape victims discuss conception due to corrective rape and how this affects the mother-child relationship. Feedback from victims include coping mechanisms from religious beliefs to alcohol abuse. None of the rape-survivors interviewed in this study contracted HIVIAIDS as a consequence of the rape.
\end{abstract}

Keywords: stigmatisation, townships, HIVIAIDS, sexuality, rape, discrimination, gender, black lesbian, rape culture, hate crime, sexual violence

\section{Introduction}

Societal rape culture, an environment where sexual assault and abuse is underplayed and effectively normalised, "satirizes, lyricizes, justifies and excuses violence against women and in turn supports the concept that sexual violence is structurally integrated at all levels of society" (Buchwald et.,2005; Dines,2010; Katz,2006; Rose \& Koss, 2001, p1296). They contend that sexual violence is an interrelated behavioral response thereby normalising it in many societies across the world; while the general consensus is that sexual violence is not gender-specific, children and women are more vulnerable to exploitation (World Health Organization, 2013; pg. 2) ${ }^{1}$.

However, men and LBGTI individuals are also targeted to fall victim to acts of sexual violence; in these instances women are known to assume the role of perpetrator. What is the connection between sexual violence and the societal rape culture? According to Buchwald et al, 2005) ${ }^{2}$ the concept of rape culture derives from a particular set of ideas or beliefs that are justified within a given society, solely based on certain attitudes, beliefs, customs, rituals and ideologies its members securitised and sanctioned as acceptable and normal.

This claim was authenticated based on their extensive empirical analysis of the high incidence of sexual violence carried out across the world, consequently a culture that justifies sexual violence is normalised through a collective belief system

\footnotetext{
1 World Health Organization. (2013). Global and regional estimates of violence against women: prevalence and health effects of intimate partner violence and non-partner sexual violence. World Health Organization. Global and regional estimates of violence against women: prevalence and health effects of intimate partner violence and non-partner sexual violence, p.2. See more at: http://www.unwomen.org/en/what-we-do/ending-violence-against-women/facts-and-figures\#sthash.fOmWBVwg.dpuf

2 Buchwald, E., Fletcher, P. R., \& Roth, M. (Eds.). (2005). Transforming a rape culture (p. XI). Minneapolis, MN: Milkweed Editions.
} 
that validates sexism, misogyny and patriarchy; in other words, the common consensus within select societies is that sexual violence is a valid retaliation institutionalised through misconceptions that exercising power and control over vulnerable people is acceptable.

Fostering a rape culture that is synchronised through sexual violence is today an escalating global social problem. This phenomenon is not unique to South Africa; my research of what constitutes hate crime is ongoing and in this instance focuses on the people living in Cape Town townships, located in South Africa's Western Cape Province. My research study poignantly examines the incidence of sexual violence within the global arena. The International Statistic on Rape per 100,000 people ${ }^{1}$ across the globe shows some gross facts about rape and rapists, and the individuals exposed to sexual violence and abuse.

However, these statistics are insignificant because the varied acts of sexual violence are difficult to measure; using a single source as a means to explain the provocation to commit a bias-motivated assault is not conclusive. It is also difficult to establish one coherent or holistic view on rape, which unlike crimes related to homicides sexual violation is culturally ingrained and normalised even in a country like Sweden where I call home.

The rape culture in Sweden tallies a frequency rate five hundred times higher than Pakistan (Karlin, \& Reed, 2017) 2; in the United State on average 321,500 reported cases are about victims aged 12 years and older who are raped and sexual assaulted every year (Victims of Sexual Violence: Statistics | RAINN", 2017).

3 In another study on male perpetration of raping non-partner women and of men Fulu, Jewkes, Roselli, \& Garcia-Moreno $(2013)^{4}$ reveal what the rape factors are from nine locations in Asia and the Pacific across six countries -- Bangladesh, China, Cambodia, Indonesia, Papua New Guinea, and Sri Lanka. The research was conducted between January 2011 and December 2012 on males aged 18-49 years; the results show that rape perpetration has a high rate frequency, committed by males in the countries under investigation. A similar study was carried out in other countries, including South Africa.

The results of the analysis show that further in-depth research on rape perpetration is necessary; in particular sexual violence that is culturally motivated parallel to male gender norms that are driven by dominance needs to be addressed. However, the above sexual violence studies excluded LGBTI communities and gender non-confirming persons inflicted by male offenders. Because a rape culture society normalises sexual violence, such as spousal rape, which is not considered rape as the men believe they are entitled to have intercourse with their spouse whenever they want.

The conclusion of the research study speaks about multiple perpetrator acts of rape as cultural or subcultural practice; in South Africa it is referred to as streamlining (Wood, 2005. page 215; also see also Jewkes et al., 2009. Pg.215) ${ }^{5}$ which is a way of rationalising culturally connected norms embedded and rooted to sexual entitlement and sexual relationship. In addition, further investigation of the sexual relationship between husband and wife the study reveals that men commonly raped because "not only did they feel inclined to forcibly conduct intercourse, they also felt entitled to a violent sexual encounter as well as being entertained by the notion that rape is a "deserved punishment for women" (ibid).

The above study found similar responses from South African men when the same questions were put to them (ibid). ${ }^{6}$ The results were compared to the study done in South Africa whereby one out of four men ( 28 percent) stated that they had

\footnotetext{
${ }^{1}$ Karlin, A., Karlin, A., \& Reed, F. (2017). Rape Culture Around the World. The Unz Review. Retrieved 17 April 2017, from http://www.unz.com/akarlin/global-rape-culture/

2 Karlin, A., Karlin, A., \& Reed, F. (2017). Rape Culture Around the World. The Unz Review. Retrieved 17 April 2017, from http://www.unz.com/akarlin/global-rape-culture/

${ }^{3}$ Department of Justice, Office of Justice Programs, Bureau of Justice Statistics, National Crime Victimization Survey, 2010-2014 (2015)

${ }^{4}$ Fulu, E., Jewkes, R., Roselli, T., \& Garcia-Moreno, C. (2013). Prevalence of and factors associated with male perpetration of intimate partner violence: findings from the UN Multi-country Cross-sectional Study on Men and Violence in Asia and the Pacific. The Lancet Global Health, 1(4), e187-e207. http://dx.doi.org/10.1016/s2214-109x(13)70074-3

5 Wood, K. (2005). Contextualizing group rape in post-apartheid South Africa. Culture, Health \& Sexuality, 7(4), 303-317.
}

6 Jewkes, R., Christofides, N., Vetten, L., Jina, R., Sigsworth, R., \& Loots, L. (2009). Medico-legal findings, legal case progression, and outcomes in South African rape cases: retrospective review. PLoS Med, 6(10), e1000164. 
committed rape, in contrast with a non-partner whereby rape of women in marriage had a higher frequency than was the case of non-partner rape in South Africa (Fulu, Jewkes, Roselli, \& Garcia-Moreno, 2013, page,214).

The results also show that a quarter of the male perpetrators brought to justice were jailed and legally charged for committing sexual violence; the conviction rate is higher than South Africa, whereby 32 percent of adult rape cases were reported and 4 percent of child rapes resulted in a conviction compared to the six countries investigated in the research study with the exception in Papua New Guinea. While these results are in stark contrast to South Africa the study showed the proportion of non-partners striking more than half ( 57.5 percent) were first time teenage rape perpetrators; the numbers fluctuated between 33 percent and 66 percent by country; this number shows lower compared to that of South Africa and the USA, which is 75 percent (Jewkes et al., 20091)

This study was carried out in nine cities in Asia and Pacific across six countries, Bangladesh, China, Cambodia, Indonesia, Papua New Guinea, and Sri Lanka where the men in the studies believe they are entitlement to sexual relationships; the results were compared with similar studies carried out in South Africa (Jewkes, R. (2012)2.

Another study undertaken by Sigsworth $(2009, \mathrm{pg} .18)^{3}$ uses the term 'rape culture' to describe a belief system that accepts sexual violence as normal, and the very act of rape is not viewed as a social threat or in any way harmful; in addition, rape is not regarded as a criminal offence by the police, court, perpetrator or society (pg. 18). Throughout the introduction chapter I demonstrated the link between rape culture and sexual violence using different sources to illustrate the interrelated concepts between a rape culture and sexual violence to explore the adverse influence hate crimes have on LGBTI people.

In this study I explored the prevailing corrective/curative rape phenomena as a form of rape culture within the townships of South Africa and contend that an alternative concept would be to label sexual violence against lesbian women as a hate crime. The above studies show that although LGBTI individuals, located within communities throughout the world, generally face homophobic attitudes, violence and discrimination from a wide cross section of members of society; these attitudes are however not universal (Nelson,2005) ${ }^{4}$. Gay and lesbian relationships are illegal in 80 countries around the world and in five of those countries it is punishable by death (Mieses 2009) ${ }^{5}$. It is common for homophobes in these countries to say that homosexuality is not natural within their particular cultures (see for example Hoad $2000^{6}$ and Gunkel 20107).

Although evidence reveals that African men and women have engaged in same sex intercourse from pre-colonial to postcolonial eras (Xin Ling 2009:1; Murray \& Roscoe 1998), African countries are generally intolerant of same sex relationships, with punishment including imprisonment and death penalties (Morgan \& Wieringa 2005:658). These practices constitute "legally mandated homophobic intolerance" (Horn, 2006:7); the above studies show that LGBTI people living in countries that have a high frequency of homophobic attitudes and consequently have been discriminated against, and raped and murdered due to their sexual orientation. Sexual orientation must conform to strict cultural norms; religion is prescriptive and hard-core in regard to the acceptable definition of sexuality and sexual orientation. Accordingly, heterosexuality -sexual activity between male and female -- is considered to be the standard norm and only way to engage in sexual intercourse.

\footnotetext{
1 Jewkes, R., Christofides, N., Vetten, L., Jina, R., Sigsworth, R., \& Loots, L. (2009). Medico-legal findings, legal case progression, and outcomes in South African rape cases: retrospective review. PLoS Med, 6(10), e1000164.

${ }^{3}$ Sigsworth, R., \& Rapist, A. C. B. A. (2009). An Overview of Sexual Violence in South Africa.

${ }^{4}$ Nelson, C. (2005). Sexualized Violence Against Lesbians. Peace Review, 17(2-3), 163-180.

http://dx.doi.org/10.1080/14631370500332882

${ }^{5}$ Msibi, T. 2009. Not crossing the line: Masculinities and homophobic violence in South Africa. Agenda: Empowering women for gender equity, 23(80), pp.50-54

${ }^{6}$ Hoad, N. (2000). "Arrested development or the queerness of savages." Postcolonial Studies 3/2: 133-158.

${ }^{7}$ Gunkel, H., 2010. The cultural politics of female sexuality in South Africa. London: Routledge. Hames, M. (2007). Sexual identity a transformation at a South African university. Social Dynamics, 33(1), 52-77.

doi: $10.1080 / 02533950708628743$

${ }^{8}$ Morgan, R., \& Wieringa, S. (2005). Tommy boys, lesbian men, and ancestral wives: Female same-sex practices in Africa. Johannesburg, South Africa: Jacana Media.
} 
Research (Polders and Wells, 2004; Potgieter, 2004) ${ }^{1}$ conducted in Tshwane, South Africa on Lesbian, Gay and Bisexual people showed that 37 percent of the study sample population ( $\mathrm{N}=487$ ) experienced verbal harassment or abuse based on their sexual orientation (Polders and Wells, 2004), while 15 percent of the sample participants had been asked to leave their faith or religious communities because of their sexual orientation (Polders and Wells, 2004; Potgieter, 2004) ${ }^{2}$. The vast research on sexual violence against LGBTI people illustrates that homophobia is seen as an attempt to dissuade gender non-conforming goings-on, with the intention of preventing the systematic breakdown of normal gender socialisation. This approach directly challenges the LGBTI categories of men and women to understand the meaning and purpose of God's creation of humankind. The Christian faith as taught in the Bible states that God created man and woman to populate the world within the union of marriage (Genesis) and that the norm of heterosexuality be considered divine and sacred.

A diverse body of research on homophobia and heterosexism speaks about the parallel between (Barrett, 1997; Coyle and Kitzinger, 2002; Dunphy, 2000; Paechter, 2000; Richardson and Seidman, 2002) sexual violence and gender-based relationships. Relevant studies explain that there exists a correlation between religion, cultural tradition and apartheid; they contend that these belief systems are the main culprits that manifest homophobia and stigma associated with sexual assault.

Bias attitudes toward women and LGBTI people, which even to this day remain unchallenged, allegedly stem from authoritarianism during colonisation and sexual victimisation of the perpetrator. However, research on how a rape culture is instilled is in short supply apart from studies by scholars engaged with sexual violence scripts in South Africa. Documenting the impact rape has on survivors is important knowledge to identify sexual assault responses and prevention; this approach to sexual assault as a punishable crime deals with various people advocating for criminal and social justice as well as policymakers.

Reid (2010: 38) points out a serious gap between the "ideals of the South African constitution and reality", while Hames (2007: 53) argues that "South African society is still deeply conservative, divisive, homo-prejudiced and racist." In this light, legal policies fail to offer adequate protection for lesbians and gay men in South Africa (Gibson, 2010; Empowering Women for Gender and Equity, 2006). This is exemplified in Smith's (2003:12) chilling claim that when lesbians are attacked there is rarely the same public outrage as that reserved for the abuse of straight women.

Gontek (2009) contends that many lesbians who choose to practise their non-conformist sexual orientation freely inevitably face economic discrimination, social isolation and cultural rejection. This discrimination is made worse by being vulnerable to physical violence. Gontek (2009) notes that lesbian women, especially those who challenge normative attributes of masculinity through their dress code, behaviour and appearance, have been subjected to sexual violence, including corrective rape, as a form of punishment. Research conducted by the Pew Research Centre (2013) reveals that 61 percent of South African adults are of the opinion that same sex relationships should not be tolerated in South Africa while 38 per cent are in favour. The younger generation, especially young females and well educated liberal and less religious people tend to be more in favour of and tolerant of same sex relationships. According to the HSRC Progressives Prudes report, homophobic attitudes are shared fairly equally among South Africans of different 'race' groups (HSRC 2016). The Progressive Prudes report (2016) investigates public attitudes toward homosexuality and other gender non-conforming persons; South Africa scores a lower percentage of 'for and against' votes, in contrast to other statistics cited following a survey regarding LGBTI homophobia attitudes done previously in South Africa.

According to the survey there was a drop between five and ten per cent, compared what was cited by various studies on homophobia attitudes. These studies were carried out statistically, which means different research studies produced different results; however, the report did not mention any marginal errors in their poll or in their studies. The survey was conducted face-to-face in private with select interviewees. It is the author's opinion that although the feedback to the questions seemed to have had a positive conclusion, the survey questions lacked concrete variability in terms of ethnicity and race to allow analytic measurement.

\footnotetext{
${ }_{1}^{1}$ Polders, I., \& Wells, H. (2004). Levels of empowerment among lesbian, gay, bisexual and transgender [LGBT] people in Gauteng, South Africa. Retrieved from the OUT
}

2 ibid 
If homophobia is seen as an un-African or un-Christian viewpoint in opposition to the traditional culture in South Africa then the survey question should instead have been worded more explicitly. "As a South African have you been sexually attracted to someone of the same sex?" In a society rape-culture is synonymous with the normalisation of sexual violence; as such we might expect a different result when the survey questions elicit a broad spectrum of responses. This study also reveals attitudes toward LGBTI individuals who were assaulted due to cross-dressing.

\section{Literature Review}

Minorities who are gay, lesbian or a gender non-conforming person are at risk of sexual abuse by perpetrators whose actions are motivated by a belief that the victim's sexual orientation is cured and corrected through rape (Phamodi,2011). The concept of corrective rape emerged in the early twenties in South Africa; once this form of sexual violence became a frequent occurrence it became known as a phenomenon. This concept was coined by human rights organisations in recognition of sexual violence as a punishable crime.

Bringing persons intent on sexually assaulting non-conforming individuals to justice was placed on high alert (Phamodi, 2011) ${ }^{1}$ as well as persons driven by the purpose of raping individuals as a way of curing them of their unconventional sexual orientation (Lake, 2014) ${ }^{2}$. Large scale debate in both South African and international media ensued on the topic of sexual violence; in addition, contemporary public discourses and scholarly reports on anti-sexual violence encouraged earnest debate and research into the corrective rape phenomena taking place in South African townships (Msibi 2011; Sanger 2010). ${ }^{3}$

Silvio (2011: 1471) has noted that some men "correct and cure lesbians and those of nonconforming sexual orientation through corrective rape". Other scholars have made similar claims in their research about homophobic attacks in the form of corrective rape. Homosexuality is historically viewed as un-African (un-Indian-Muslim-un-British, un-Christian ${ }^{4}$ ); even today homophobic attitudes are directed at people practising same gender sexual orientation.

Alternative non-conformist sexual orientations are deployed within various cultural norms and traditions; different perceptions of sexual orientation are evident within moral, virtuous or political environments. Along with research studies undertaken by Silvio (2011) and other extensive scripts pertaining to research on sexual violence, the motive behind corrective rape is due to traditions, gender inequality, hate crime, male entitlement to sex, weak legal framework failing to prosecute perpetrators, sexual politics, poverty, apartheid history, structural discrimination and racism interlocks gender sexuality, sexual orientation, and sexual identity (Jewkes, 2002; Vetten, 2004 Coyle and Kitzinger, 2002; Jewkes, Moffett,2006; Posel, Vetten, Wood,2005; Samelius and Waigberg, 2005,Sigsworth etc.)

The next section of this research study debates the concept of corrective/curative rape and discusses language barriers and problems associated with using such terminology in this study. Consequently an alternative concept that describes hate crime is deployed in this study, to not offend but rather to validate the seriousness of the criminal act. I provide justification of my decision to use alternative terminology to describe the phenomena of corrective/curative rape in my dissertation; this is in keeping with the work of Kruger (2006) who opts for the approach and use of the concept hate crime (corrective/curative rape) by exploring the trauma of sexual violence experienced by black lesbians currently living in Cape Town townships. Choosing terminology that aptly describes gender roles and social orders that are not only rooted but also dismantled within the gendered social institution, is critical.

Kruger (2006) discusses specifically corrective rape as a hate crime; she debates lesbianism including butch (masculine) lesbian sexuality. Rape or sexual assault is carried out to demonstrate that women are at the mercy of men to exercise full control of their lives. Corrective/Curative rape is motivated by the belief that lesbians are women who 'pretend' to be male

\footnotetext{
1 Phamodi, S. J. (2011). Interrogating the notion of "corrective rape" in contemporary public and media discourse. Retrieved from "Interrogating the Notion Of 'Corrective Rape' In Contemporary Public and Media Discourse - Gender Links". Gender Links. N.p., 2017. Web. 15 Apr. 2017.

2 Lake, N. (2014). Black lesbian bodies-reflections on a queer South African archive. Africa insight, 44(1), 69-83.

${ }^{3}$ Msibi, T. 2011. "The Lies we have been told: On (Homo) Sexuality in Africa". Africa

Today. Vol. 58, no. 1, pp. 55-77. Sanger, N. 2010. „The real problems need to be fixed first: Public discourses on sexuality and gender in South Africa". Agenda: Empowering women for gender equity. Vol. 24, no.83, pp. 114-12
}

${ }^{4}$ Gunkel, H. (2010). The cultural politics of female sexuality in South Africa. Routledge.Page 27 
and the forced sexual encounter is designed to 'prove' that they are women. 'The idea that all lesbians need to convert to become heterosexual 'thanks to' heterosexual intercourse, making corrective/curative rape extremely prevalent in some communities in South Africa" (Kruger 2006: 13-16).

Kruger criticises homophobic attitudes and acknowledges that supporting legitimised heterosexuality as the natural order, whereby lesbians are subordinated (Moffett, 2006) ${ }^{1}$ by traditional gender roles. Along with Kruger (2006) Levin and McDevitt (2002: 240-255) ${ }^{2}$ who endorsed corrective rape as a hate crime and differentiated it from any other form of sexual violence as it is carried out to alter gender identity, and focuses on a specific group of people. Harris too points out (2004) $)^{3}$ that corrective rape is viewed as a hate crime which he calls a "message crime" in which lesbians are targeted to convey a message of homophobic intolerance.

While anti-sexual violence scholarship authors (Msibi 2009, Nel \& Judge 2008) continue this line of thought, other scholars (Kruger, 2006; Levin \& McDevitt, 2001; Harris 20044) argue that sexual violence aimed at lesbians is motivated by homophobia and that the perpetrator adopts an entitled expectation to exercise the power to control groups of women to intrude on their non-conforming gender identity. The criminal justice system in South Africa violates and contradicts its own laws on homophobia and human rights conventions, which take form through state institutions. Criminal justice and law enforcement, carried out by the police services, instils fear that victims may also experience secondary victimisation by justice system personnel upon entering the criminal justice system.

The re-traumatisation of the sexual assault, abuse, or rape victim through the responses of individuals and institutions is an example of secondary victimisation. ${ }^{5}$ Victims are made aware that sexual violence has a political agenda in that rape frequency fuels the spread of HIVIAIDS, a pandemic that is crumbling the South African public healthcare system ${ }^{6}$. The flaws that are evident in the concept of corrective/curative rape is further debated by Gqola in her book Rape the South African nightmare; Gqola (2015) argues against the concept of 'corrective rape' and states that rape categories between heterosexual women and lesbian rape survivors are discriminatory against women because sexual violence against lesbian women seems too farfetched and presumed much more traumatic compared to sexual assault against heterosexual women.

Gqola takes a stand in her book that all incidents of rape should be considered equally, irrespective of whether the sexual assault is inflicted on lesbian women or heterosexual women. However, the author provides no evidence in her book that indicates whether any qualitative or quantitative studies were carried out to show that the account of the violent incident given by rape-survivors is universal. Moreover this fact would backup Elizabeth Spelman's point of view about the dangers women face within a patriarchal sexually-biased society: "For essentialism invites me to take what I understand to be true of me 'as a woman' for some golden nugget of womaness all women have as women". ${ }^{7}$ Furthermore, she did not provide substantial argument how LGBTI people, as sexual minorities and heterosexual women, are able to speak out to express an opinion and claim their agency in terms of them being targeted to endure rape and sexual violence.

The same applies to LGBTI people having to resign themselves to a life of prejudice and experience sexual assaults; as women we come from diverse groups of people from different economic systems and therefore make up a diverse socialcultural-political race consisting of a multitude of ethnic classes each with a distinctive gender identity. The very fact that all women, including LGBTI women have ovaries (my concept) does not necessarily mean all rape survivors interpret the

\footnotetext{
${ }^{1}$ Moffett, H. (2006). 'These women, they force us to rape them': Rape as narrative of social control in post-apartheid South Africa. Journal of Southern African Studies, 32(1), 129-144.

Men use to inscribe subordinates' status on to an intimately known "other"- women page 130

2 Levin, J., \& McDevitt, J. (2002). Hate crimes revisited: America's war on those who are different. Boulder, CO: Westview Press.

3 Harris, B. (2004). Arranging prejudice: Exploring hate crime in post-apartheid South Africa. Cape Town: Centre for the Study of Violence and Reconciliation. (2017). Retrieved 16 April 2017, from

http://citeseerx.ist.psu.edu/viewdoc/download?doi=10.1.1.532.6406\&rep=rep1\&type=pdf
}

${ }_{5}^{5}$ Thoreson, R. (2008). Somewhere over the Rainbow Nation: Gay, Lesbian and Bisexual Activism in South Africa*. Journal of Southern African Studies, 34(3), 679-697. http://dx.doi.org/10.1080/03057070802259969

${ }^{6}$ Thoreson, R. (2008). Somewhere over the Rainbow Nation: Gay, Lesbian and Bisexual Activism in South Africa*. Journal of Southern African Studies, 34(3), 679-697. http://dx.doi.org/10.1080/03057070802259969

7 Elizabeth V. Spelman, Inessential Woman (Boston: Beacon Press.1988), 159 
assault as a bias-motivated sexually violent deed. However, other forms of gender-based violence are perceived as any act that is likely to result in physical, sexual or psychological harm or suffering to women; threats include coercion or arbitrary deprivation of autonomy to live a life as gender non-conforming individuals. This is a universal attitude whereby women share their heart breaking stories of being raped and their life experiences.

I maintain that women and gender non-conforming minorities are vulnerable to sexual assault especially during times of war; the trauma brought on by rampant genocide creates a climate that legitimises mass rape, which is viewed by perpetrators as a weapon of war and genocide. However, I am not implying hate crime rape survivors are unique, yet according to democratic theory women and self-identified LGBTI people or other sexual non-conforming gender minorities must be respected for their individualism.

Gay men and heterosexual men have the right to speak about their sexual experiences so that they may express the trauma endured as a result of sexual assault and rape. In addition, by exposing perpetrators guilty of this crime victims facilitate justice being served. The State acts as a buffer when it comes to passing judgement for compensation sought by victims of sexual violence against women and sexual minorities, through judicial systems.

South Africa has an uncodified legal system consisting of various sources of law, including the Constitution, legislation (including statutory laws issued by national and provincial legislative bodies and subsidiary legislation), judicial precedent, customary law, common law (Roman-Dutch and English law), and international law. For the purposes of this article it is crucial to differentiate between material rape, intimate partner rape, date rape and sexual assault other than the type of gender-based violence on women; this would be difficult to prove with sufficient crime categories to monitor and implement policy framework and collecting DNA evidence in terms of prosecuting the perpetrator. Here the argument of categories Gqola discusses in her book become relevant - her argument is that all women whether their sexual orientation is lesbian or heterosexual -- are equal in terms of sexual violence categories.

That all women are equal might sound innocuous and vague although Gqola (2015) in her book discusses in general the raping of women in South Africa; she points out that statistics concerning South African women who have been sexually assaulted do not form part of a universal grouping. Feminist scholars consistently argue against the assumption that women should be viewed according to a universal standard whether they are categorized as LGBTI people or heterosexual. This opinion is sanctioned by Elizabeth Spelman (1998) who points out that while feminists resist accounts that define women as having certain features that are essential to their being women, feminists are also guilty of giving essentialism definitions: "For essentialism invites me to take what I understand to be a woman. ${ }^{1}$ Because women are extremely diverse in their experiences, essentialism critics question whether a universal account of women can be given. Yet, even with diversity among women, they are oppressed by patriarchal structures such as rape, pornography, and sexual harassment (IBID).

Scholars who concede various anti-sexual violence disciplines argue that hate crimes have high-frequency rates in townships and are recognised as social problems experienced by black lesbians; sexual violence, and rape in particular, is considered the most under-reported violent crime. Reasons for individuals not reporting sexual assaults include fear of not being believed, insecurity, and fear of getting into trouble. Other reasons hate crimes are swept under the carpet are due to (1) normalisation of sexual violence by the society; (2) stigma and assimilation around black lesbian sexuality; (3) sexism and homophobia which are rooted in the socio-culture; and (4) South Africa's apartheid history, poverty, sexual identity, gender, religion and hegemonic power.

Often when an outsider such as myself hears or reads about a black lesbian in South Africa being sexually assaulted because of her alternative sexual orientation, they feel compelled to develop a greater public awareness to change the common attitude within society that the crime is somehow justified. This is precisely how I became involved in the study of female black lesbian sexuality. However, most of the research undertaken about lesbian sexuality was interrelated with HIV/ Aids studies, which is a common dualism most scholars apply when developing a research study of this nature. Therefore, this study is an attempt to fill some important gaps in the study of Black lesbian sexuality; areas that are researched in detail include identifying various intersections pertaining to everyday life experiences of Black Lesbians living in the township. 
Scholars that produce papers on anti-sexual violence rely on various disciplines to fully demonstrate their points of view. They argue that sexual violence has been conceptualised as a hate or bias-motivated crime, and that it has a highfrequency rate within townships. Sexual assault is viewed as a pervasive social problem experienced by black lesbians. These scholars validate their claims that incidents of sexual violence against black lesbians residing in townships is underreported because (1) sexual violence is hugely prevalent that society accepts it as normal; (2) stigma and assimilation around black lesbian sexuality; (3) sexism and homophobia is deeply rooted within the socio-culture; and (4) South Africa's apartheid history, poverty, sexual identity, gender and religion and hegemonic power.

\section{Goal of the study}

The goal of this study is to analyse life stories of a group of black lesbians who are rape survivors. The research group is made up of individuals who reside in Cape Town's townships. The goal of the study is to break the silence of what it means to commit a hate crime and the judicial punishment for the perpetrator. The author of this study believes that by exposing the trauma of sexual violence will help saviours the courage to heal and to improve the way and means perpetrators are prosecuted.

\section{Feminist Methodology: Life history method and feminist analysis method}

It is hereby acknowledged that feminism itself developed as a consequence of in-depth research methodologies and by way of interviewing feminists to gain their interpretations of relevant topics. The process of gathering topic-specific data meant questioning and challenging the traditional social science of feminism, grounded on rationality, objectivity and male privilege and by adopting social phenomena to facilitate the intended analysis methodology. As a result, the role of the unbiased researcher come under securitization; the approaches were questioned to validate the research using feminist methodology to underpin theories and relevant construction of women's perspectives relative to oppression and consciousness (Holloway and Wheeler 2010) 1 .

Different feminist components contributed to collating different feminist methodologies because the gender aspect is the key principle and common denominator of social status; the male gender is the Alfa, representative of privilege and dominance compared to the female gender, which is deemed the second sex. The gender hierarchy was debated and concluded that the top position was owned by powerful (men) at the cost of (subordinate) women, thereby stating that men and women occupied different positions in terms of social status ( ${ }^{2}$ Reinharz, 1983; Sarantakos ${ }^{3}, 2005$; Parahoo, ${ }^{4} 2006$; Holloway and Wheeler, 20105).

The concept of utilizing appropriate methodologies to differentiate the roles of men and women refers to a particular view of "how social investigation should be approached"' (Ramazanoglu and Holland 2002, 116). In Harding (1987) reference is made as to theories and analyses of how a study should be carried out. Klein (1983) defines methodologies as providing the rationale to the application of a particular technique, investigation and analysis. However, Gloria Wekker' states that methodology stems from the role of the researcher: "methodology provides information about the various ways in which one locates oneself-psychologically, socially, linguistically, geographically, epistemologically, sexually—to be exposed to experiences within a societal culture"(Wekker 2006,4) .

In researching hate crime against black lesbian women residing in townships in South Africa I found that 'gender' became the key concept for feminist methodologies. Various feminist thinkers influenced my understanding of the sexual violence endured by these women; my interpretations are captured by documenting life experiences of those who are vulnerable to hate crime and feedback provided by rape survivors. Feminist-specific methodologies provided me with ethical fieldwork guidelines and my own role as a researcher in the process.

\footnotetext{
1 Holloway I, Wheeler S (2010) Qualitative Research in Nursing and Healthcare. Third Edn. John Wiley \& Sons, Chichester

2 Reinharz S (1992) Feminist Methods in Social Research. Oxford University Press, Oxford

${ }^{3}$ Sarantakos S (2005) Social Research. Third Edn. Palgrave MacMillan Ltd, Basingstoke

${ }^{4}$ Parahoo K (2006) Nursing Research Principles, Process and Issues 2nd Edn. Palgrave Macmillan, Basingstoke

${ }^{5}$ Holloway I, Wheeler S (2010) Qualitative Research in Nursing and Healthcare. Third Edn. John Wiley \& Sons, Chichester

${ }^{6}$ Ramazanoglu, Caroline and Janet Holland. 2002. Feminist methodology: Challenges and choices. Thousand Oaks, CA: Sage.

${ }^{7}$ Wekker, Gloria. 2006. The politics of passion: Women's sexual cultures in the Afro- Surinamese diaspora. New York: Columbia University Press.
} 
The methodological approach applied to this research study is both feminist and qualitative because I will be working with documented rape-survivors' experiences, discussing traumatic life experiences which are personal and private and which therefore require a caring and empathetic interview stance. The research focuses on life story narratives of rape survivors (Harding 1992:184-185). Listening to women's stories will contribute to the production of knowledge and to generate new knowledge about a marginalized group (Smith 1992:2).

Capturing the voices of the participants in their own time and space will be important, because their stories will provide a better understanding of hate crimes toward black lesbians. Life stories of rape survivors provide information on social categories, such as gender and ethnicity, class and sexuality in their everyday lives.

\section{Method}

The study employed qualitative in-depth interviews that were documented via a MP3 device; the size of the sample is not large as it's a qualitative method deciphering in-depth life stories. The collective case study comprises seven life stories of self-identified rape-survivors and interview feedback from two police officers (male and female); the male police officer is retired from the force. He had worked at the Khayelitsha township police station and held the position of chief of police for 30 years. The female police officer hails from Langa; the interview with her is a combination of feminism analysis technique and an interpretive method used to describe the participants' experiences as a rape-survivor.

The research is still ongoing therefore I have not yet arrived at the final process analysis. Currently I'm in the $2^{\text {nd }}$ stage of analyzing the transcription of the interview therefore I can't predict the outcomes as to when the study will be finalized. I started my field work in 2015 in Cape Town and expect to conclude the fieldwork at the end of 2018. The participants are active members of the Triangle Project in Cape Town and Free Gender in Khayelitsha Township. Social workers at the Triangle project also had been interviewed along with the Manager of the Triangle Project.

\section{Conclusion}

I have arrived at a preliminary conclusion although I am at the $2^{\text {nd }}$ stage of interpreting the interview materials. Out of the 7 rape-survivors that I interviewed the youngest participant currently attending university submitted a police report and took her case to the criminal court. She was victimised twice by different perpetrators in the township where she resides. Five of the rape-survivors' claim to be able to identify their assailants, 2 of the perpetrators are family members. The age of the rape-survivors makes for significant outcomes; 4 of the women who were sexually assaulted were still attending school at the time the rape took place.

Three of the victims became pregnant as a result of the rape and describe the conception as very painful and emotional as the child was unwanted. The babies born post-rape were placed in the care of the maternal family; the child and mother have no connection with the father/perpetrator. I also determined that the township was established during the country's apartheid system; the residential area is predominately occupied by low income groups of black people, most of whom are unemployed. The rape-survivors confirm that circumstances in the township are not ideal due to the high level of crime; their fear of being victimised multiple times is not conducive to strive for a better, safe existence. None of the hate crime survivors contracted HIVIAids as a consequence of the rape yet the practice of consensual sexual relationships puts them at risk of abuse in the townships.

Note- Do note cite this paper as it is on going PhD Project under the supervision of Supervisor: Michael Drewett; Rhodes University South Africa.

\section{Acknowledgements}

At this moment, I, J.K. Wilson, have no financial benefits from any organisation or personal relationship in shares that may have inappropriately influenced me in writing my $\mathrm{PhD}$ dissertation, which is presented as a part of the conference chapter. 